\section{Biosolids Impact Antioxidant Metabolism Associated with Drought Tolerance in Tall Fescue}

\author{
Xunzhong Zhang ${ }^{1,2}$ \\ Department of Crop and Soil Environmental Sciences, Virginia Tech, \\ Blacksburg, VA 24061
}

Damai Zhou'
Hebei Mountain Area Research Institute, Agricultural University of Hebei,
Baoding, Hebei, China 071001

Erik H. Ervin, Greg K. Evanylo, Derik Cataldi, and Jinling Li

Department of Crop and Soil Environmental Sciences, Virginia Tech, Blacksburg, VA 24061

Additional index words. organic amendment, antioxidant, auxin, biosolids, turfgrass, water deficit

\begin{abstract}
The presence of biologically active substances (BAS) in biosolids may enhance plant stress tolerance and growth, but the underlying mechanisms are not well understood. This greenhouse study investigated the effects of two biosolids: Alexandria (anaerobically digested; Class A product from the Alexandria Sanitation Authority Wastewater Treatment Facility in Alexandria, VA) and Blue Plains (lime-stabilized; Class B product from Washington, DC, Water and Sewer Authority) on tall fescue [Lolium arundinaceum (Schreb.) S.J. Darbyshire] antioxidant enzyme activity associated with drought resistance. Treatments included a fertilizer control, Alexandria (11.9 $\mathrm{g} \cdot \mathrm{kg}^{-1}$ soil) and Blue Plains (17.6 $\mathrm{g} \cdot \mathrm{kg}^{-1}$ soil) biosolids to match the nitrogen in the control. Tall fescue physiological responses were measured under well-watered or drought-stressed conditions. Drought stress reduced turfgrass quality, photochemical efficiency (PE), and catalase (CAT) activity while increasing superoxide dismutase (SOD), ascorbate peroxidase (APX), and peroxidase (POD) activities. The two biosolids improved turfgrass quality and root mass under both soil moisture regimes and delayed leaf wilting during moisture stress. The biosolids also improved PE, SOD, and APX activities relative to the control under both soil moisture regimes. The data suggest that biosolids application may improve antioxidant enzyme activity and subsequent drought resistance.
\end{abstract}

Biosolids are valued as sources of plant nutrients, soil organic matter, and, in the case of alkaline-stabilized materials, liming agents (U.S. EPA, 2007; Zhang et al., 2009). The addition of organic materials enhances the biological, physical, and chemical properties of the soil with yield improvements usually being associated with increased nutrient availability (Akrivos et al., 2000; Boquet et al., 1999; Bugbee, 2002; Gilmour et al., 2003; Tester, 1989) and, sometimes, to improved soil physical properties (Klock-Moore, 2000). Recent evidence indicates that biosolids may contain BAS that enable crops to withstand environmental stresses (e.g., drought, salinity, pathogens) and/or positively affect crop growth and quality (Subler et al., 1998; Zhang et al., 2005, 2007, 2009).

Several groups of BAS (e.g., humic substances, amino acids, vitamins, hormones)

Received for publication 21 May 2012. Accepted for publication 21 Aug. 2012.

${ }^{1}$ Xunzhong Zhang and Damai Zhou contributed equally to this work.

${ }^{2}$ To whom reprint requests should be addressed; e-mail xuzhang@vt.edu. superoxide radical $\left(\mathrm{O}_{2}^{-}\right)$, hydrogen peroxide $\left(\mathrm{H}_{2} \mathrm{O}_{2}\right)$, and hydroxyl radical $\left(\mathrm{OH}^{-}\right)$(Zhang and Ervin, 2004). During drought stress, an abscisic acid signal causes stomatal closure and light-exposed, over-reduced photosynthetic systems may experience oxidative stress and overproduction of ROS. Excess ROS may cause severe damage to important cellular components such as proteins, lipids, and nucleic acids, leading to cell death. Plants have evolved a complex antioxidant defense system (i.e., enzymatic and non-enzymatic detoxification systems) for protecting cells from ROS injury.

SODs are metalloenzymes that convert $\mathrm{O}_{2}^{-}$to $\mathrm{H}_{2} \mathrm{O}_{2}$ and are considered the "primary defense" against ROS (Perl-Treves and Perl, 2002; Zhang and Schmidt, 1999, 2000). In this system, $\mathrm{H}_{2} \mathrm{O}_{2}$ is further reduced to water by CAT and APX. Catalase, localized in peroxisomes, scavenges $\mathrm{H}_{2} \mathrm{O}_{2}$ produced by glycolate oxidase in the $\mathrm{C}_{2}$ photorespiratory cycle (Perl-Treves and Perl, 2002). POD is also an important antioxidant enzyme for scavenging ROS. There is a complex signaling network governing antioxidant defense with plant hormones playing an important role in signaling plant defense responses (Strivastava, 2002).

Tall fescue, a cool-season turfgrass, is widely used for home lawns, recreational surfaces, and roadsides in the temperate to semitropical United States and experiences frequent summer drought stress. Little previous research has been reported on the impact of biosolids on antioxidant metabolism associated with drought tolerance in tall fescue. The objectives of this study were to investigate effects of biosolid applications on drought tolerance associated with antioxidant metabolism and root growth under differential soil moisture availability.

\section{Materials and Methods}

solidentified and isolated from bioMonedero et al., 1999; Zhang et al., 2005). The presence of BAS in biosolids may enhance crop production by providing plant growth regulators directly or by stimulating the activity of microbes that supply substrates and hormones. Auxin, an important phytohormone, has been shown to improve root growth and stress tolerance in turfgrasses (Zhang et al., 2009). It was found that biosolids contained auxin [indole-3-acetic acid (IAA)] at physiologically active levels (Zhang et al., 2009). Microbial production of IAA from tryptophan has been shown in a number of cases (Arshad and Frankenberger, 1993; Barea et al., 1976; Lebuhn et al., 2007). In addition, Zhang et al. (2005) measured IAA contents of the humic acid fraction of variously processed biosolids to range from 0.5 to $2.4 \mu \mathrm{g} \cdot \mathrm{g}^{-1}$. Plant hormones, particularly IAA in the biosolids, may account for some of the beneficial effects previously reported on plant growth and physiological fitness.

Environmental stresses such as drought may cause damage to plant cells through production of excess reactive oxygen species (ROS) such as singlet oxygen $\left({ }^{1} \mathrm{O}_{2}\right)$,

\section{Biosolids characterization}

One anaerobically digested biosolids (Alexandria) and one lime-stabilized biosolids (Blue Plains) were used in this study. The Alexandria biosolids, obtained from the Alexandria Sanitation Authority Wastewater Treatment Facility (Alexandria, VA), are Class A products (with respect to pathogens) stabilized by anaerobic digestion and pasteurization (Process to Further Reduce Pathogens). The Blue Plains biosolids, obtained from the Washington, DC, Water and Sewer Authority, are Class B products stabilized by lime stabilization (Process to Significantly Reduce Pathogens). Both products were dewatered to permit easy handling and spreading. Moisture content and carbon and nitrogen concentrations in the biosolids were determined by A\&L Laboratories, Inc. (Richmond, VA). Total Kjeldahl nitrogen (TKN) was determined by EPA method 351.3 (U.S. EPA, 1979); $\mathrm{NO}_{3}^{-} \mathrm{N}$ by method $\mathrm{SM} 4500-\mathrm{NO}_{3} \mathrm{~F}$ (American Water Works Association, 1998); $\mathrm{NH}_{4}{ }^{+}-\mathrm{N}$ by EPA method 350.2 (U.S. EPA, 1979), and total organic carbon by EPA method 415.1 (U.S. EPA, 1979). 


\section{Biosolids auxin analysis}

Each biosolids sample $(100 \mathrm{mg})$ was extracted in $2.0 \mathrm{~mL} \mathrm{Na-phosphate} \mathrm{buffer}$ (0.05 M, pH 7.0$)$ containing $0.02 \%$ sodium diethyldithiocarbamate as an antioxidant overnight and centrifuged at $10,000 g_{n}$ for $10 \mathrm{~min}$. The supernatant was collected. An internal standard of ${ }^{13} \mathrm{C}_{6}$-IAA (50 ng) was added into each and extracted by continuous shaking for $1 \mathrm{~h}$ at $4{ }^{\circ} \mathrm{C}$. The samples were transferred into 2.0-mL microcentrifuge tubes after extraction and $\mathrm{pH}$ was adjusted to $\approx 2.6$ with $1.0 \mathrm{M} \mathrm{HCl}$. The sample was slurried with $150 \mathrm{mg}$ of Amberlite XAD-7 (Sigma-Aldrich, St. Louis, $\mathrm{MO})$ for $30 \mathrm{~min}$. After removal of the buffer, the XAD-7 was washed with $2 \times 1 \mathrm{~mL}$ of $1 \%$ acetic acid before being slurried with $2 \times 1 \mathrm{~mL}$ of dichloromethane for $30 \mathrm{~min}$ each time (Edlund et al., 1995). The combined dichloromethane fractions were reduced to dryness with $\mathrm{N}$ gas.

IAA was assayed using a linear ion trap quadrupole liquid chromatography-tandem mass spectroscopy (3200 Q Trap model; Applied Biosystems, Foster City, CA). An Agilent Zorbax SB-C18 column $(4.6 \times 7.5 \mathrm{~mm}$, i.d.: $3.5 \mu \mathrm{m}$ particle size) was used and eluted with a mixture of methanol:water containing $0.05 \%$ acetic acid (gradient from 95:5 to 10:90 to $95: 5$ in $10 \mathrm{~min}$ ) at a flow rate of $1 \mathrm{~mL} \cdot \mathrm{min}^{-1}$ and a temperature of $30{ }^{\circ} \mathrm{C}$. The sample was injected at a volume of $25 \mu \mathrm{L}$ on an autosampler (Agilent 1200 highperformance autosampler SL). The liquid chromatography ultraviolet detector was set at $280 \mathrm{~nm}$. Retention time for IAA was $\approx 5.7$ min. Generally, signal-to-noise $(\mathrm{S} / \mathrm{N})$ ratio of 3 is considered as the limit of detection and $\mathrm{S} / \mathrm{N}$ of 10 as limit of quantification. When the injection volume at $50 \mu \mathrm{L}, \mathrm{S} / \mathrm{N}$ ratio was 4.8 when IAA concentration was $1 \mathrm{ng} \cdot \mathrm{mL}^{-1}$ and $\mathrm{S} / \mathrm{N}$ ratio was 11.4 when the IAA concentration was $5 \mathrm{ng} \cdot \mathrm{mL}^{-1}$. Therefore, the limit of detection for IAA in the biosolids samples was $1 \mathrm{ng} \cdot \mathrm{mL}^{-1}$. The IAA concentration was calculated based on the internal standard and expressed as $\mu \mathrm{g} \cdot \mathrm{g}^{-1}$ biosolids.

The Alexandria biosolids contained a greater amount of TKN, $\mathrm{NH}_{4}^{+}-\mathrm{N}$, and organic $\mathrm{N}$ but a lower amount of IAA than Blue Plains biosolids (Table 1). Because of the

Table 1. Attributes of the two biosolids (Alexandria and Blue Plains) used in this study.

\begin{tabular}{lcc}
\hline Attribute & Alexandria & Blue Plains \\
\hline Solids $\left(\mathrm{g} \cdot \mathrm{kg}^{-1}\right)$ & 263 & 322 \\
Volatile solids $\left(\mathrm{g} \cdot \mathrm{kg}^{-1}\right)$ & 635 & 629 \\
$\mathrm{TKN}\left(\mathrm{g} \cdot \mathrm{kg}^{-1}\right)$ & 76.5 & 42.2 \\
$\mathrm{NH}_{4} \mathrm{~N}\left(\mathrm{~g} \cdot \mathrm{kg}^{-1}\right)$ & 21.4 & 2.6 \\
$\mathrm{Organic} \mathrm{N}\left(\mathrm{g} \cdot \mathrm{kg}^{-1}\right)$ & 55.1 & 39.6 \\
$\mathrm{P}\left(\mathrm{g} \cdot \mathrm{kg}^{-1}\right)$ & 33.5 & 10.9 \\
$\mathrm{~K}\left(\mathrm{~g} \cdot \mathrm{kg}^{-1}\right)$ & 1.7 & 2 \\
$\mathrm{~S}\left(\mathrm{~g} \cdot \mathrm{kg}^{-1}\right)$ & 9.4 & 4.5 \\
$\mathrm{Ca}\left(\mathrm{g} \cdot \mathrm{kg}^{-1}\right)$ & 20.4 & 101 \\
$\mathrm{Mg}\left(\mathrm{g} \cdot \mathrm{kg}^{-1}\right)$ & 3.3 & 2.5 \\
$\mathrm{pH}$ & 8.34 & 12.24 \\
Indole-3-acetic & 7.2 & 14.2 \\
$\quad$ acid $\left(\mu \mathrm{g} \cdot \mathrm{g}^{-1}\right)$ & & \\
$\mathrm{TKN}$
\end{tabular}

TKN = total Kjeldahl nitrogen; $\mathrm{P}=$ phosphorus; $\mathrm{K}=$ potassium; $\mathrm{S}=$ sulfur; $\mathrm{Ca}=$ calcium; $\mathrm{Mg}=$ magnesium. differences in total $\mathrm{N}$ concentrations and $\mathrm{N}$ forms between the two biosolids, the actual amount of biosolids applied to each tube was calculated based on the $\mathrm{N}$ content and estimated plant-available $\mathrm{N}$ in the biosolids Per Virginia Regulatory Agency Standard (<http://www.dcr.virginia.gov/documents/ StandardsandCreteria.pdf $>$ ); we assumed that $50 \%$ of $\mathrm{NH}_{4}{ }^{+}-\mathrm{N}$ was available and that the mineralization rate of organic $\mathrm{N}$ was $30 \%$. Based on these estimates, Alexandria was applied at $15.8 \mathrm{~g}$ per tube and the Blue Plains at $26.4 \mathrm{~g}$ per tube.

\section{Tall fescue culture, biosolids application,} and moisture stress treatment

This experiment was carried out in an environmental-controlled greenhouse at Virginia Tech, Blacksburg, VA. Plastic-lined polyvinyl chloride tubes $(10 \mathrm{~cm}$ diameter $\times$ $36 \mathrm{~cm}$ deep) were filled with gravel on the bottom $(6 \mathrm{~cm})$ and $30 \mathrm{~cm}$ calcined clay (Profile Products, Chicago, IL). A cloth $(10 \mathrm{~cm}$ diameter) was placed between the gravel and the clay to prevent migration of the calcined clay into the gravel.

On 7 Oct. 2010, Alexandria and Blue Plains biosolids were applied at 17.8 and $26.4 \mathrm{~g}$ per tube, respectively. Each tube received $1.5 \mathrm{~kg}$ calcined clay. The biosolids were mixed with $100 \mathrm{~mL}$ water and applied to the top $5 \mathrm{~cm}$ of the tubes. For the $\mathrm{N}$ control, ammonium nitrate was applied at $5.6 \mathrm{~g} \mathrm{~N} / \mathrm{m}^{2}$ on 7 Oct., 19 Oct., and 5 Nov. After initial treatment, all tubes received half-strength Hoagland's solution (Hoagland and Arnon, 1950). On 8 Oct., tall fescue 'Rebel IV' seeds were planted at $29.3 \mathrm{~g} \cdot \mathrm{m}^{-2}$. After irrigation by hand for $3 \mathrm{~d}$, the tubes were placed under a mist system. A small hole at the bottom of each tube was made to allow proper drainage. On 19 Oct., the seedlings were $\approx 2.5 \mathrm{~cm}$ tall. On 5 Nov., the grass was trimmed at a height of $2.5 \mathrm{~cm}$.

Tall fescue was grown under two soil moisture regimes: well-watered and moderate moisture stress. The "well-watered" tubes were maintained at $90 \%$ of container capacity throughout the course of the experiment by adding water on a gravimetric basis when tubes fell below $70 \%$ container capacity. All tubes were watered at same time because they reached $70 \%$ container capacity at the same time. At $90 \%$ container capacity, the moisture content of the calcined clay was $49.4 \%$. On 29 Nov., the tubes were irrigated to container capacity and allowed to drain for $24 \mathrm{~h}$ and weight of the tube at $100 \%$ container capacity was determined. For the moderate moisture stress treatment, irrigation was withheld (beginning 29 Nov.) with soil moisture in all treatments falling to near the wilting point ( $25 \%$ of container capacity) at the same time (27 Dec.); at this point, the grass was irrigated to $100 \%$ container capacity to allow recovery evaluations. The experiment was completed on 5 Jan. 2011. Leaf samples were collected on 30 Nov., 7 Dec., 14 Dec., 21 Dec., 28 Dec. 2010, and 5 Jan. 2011. The samples were frozen with liquid $\mathrm{N}$ and stored at $-80{ }^{\circ} \mathrm{C}$ for analysis of antioxidant enzyme activity.
Turfgrass quality, leaf firing, and root growth

Turfgrass quality was rated on a visual scale of 1 to 9 with 9 indicating the best quality (very dark green, dense, uniform, turgid shoots) and 1 indicating completely dead or brown shoots (Waddington et al., 1992). A rating of 6 represented minimum acceptability. Leaf firing was rated based on a visual scale of $0 \%$ to $100 \%$ with $100 \%$ indicating complete firing (or loss of turgidity) of the canopy. Root mass per pot was determined at the end of the experiment. The whole plants along with the soil were removed from the pots, and the roots were divided into two sections $(0-15 \mathrm{~cm}$ and 15 $30 \mathrm{~cm}$ deep). The roots were washed and dried at $65^{\circ} \mathrm{C}$ for $48 \mathrm{~h}$ and weighed.

\section{Photochemical efficiency}

$\mathrm{PE}$ was determined by measuring chlorophyll fluorescence with a dual-wavelength fluorometer (OS-50II; Opti-Sciences, Inc., Tyngsboro, MA). The ratio of variable fluorescence to maximum fluorescence at $690 \mathrm{~nm}$ (Fv690nm/Fm690nm or Fv/Fm) is an indicator of PE of photosystem II. Chlorophyll fluorescence was measured on a canopy rather than a single-leaf basis (Zhang et al., 2005). The values of Fv/Fm were calculated based on an average of three measurements per tube.

\section{Leaf antioxidant enzyme activity}

Frozen leaf tissues $(0.25 \mathrm{~g})$ were ground to a powder with a mortar and a pestle in liquid $\mathrm{N}$ and then the powder was homogenized with $4 \mathrm{~mL}$ cold extraction buffer [50 mM Na $\mathrm{NPO}_{4} / \mathrm{NaH}_{2} \mathrm{PO}_{4}, \mathrm{pH}$ 7, $0.2 \mathrm{~mm}$ ethylenediamine-tetraacetic acid (EDTA), and $1 \%$ polyvinylpyrrolidone]. The extracts were centrifuged at $12,000 g_{n}$ for $20 \mathrm{~min}$ at $4{ }^{\circ} \mathrm{C}$. The supernatant was collected and used for the assay of antioxidant enzymes activity (Zhang and Kirkham, 1996).

The activity of SOD was measured according to the method of Giannopolitis and Ries (1977) with modifications (Zhang and Kirkham, 1996). A 3-mL reaction mixture was composed of $50 \mathrm{~mm}$ phosphate buffer (pH 7.8), $1.3 \mu \mathrm{M}$ riboflavin, $13 \mathrm{~mm}$ methionine, $0.1 \mathrm{~mm}$ EDTA, $63 \mu \mathrm{M}$ nitro blue tetrazolium (NBT), and $0.1 \mathrm{~mL}$ enzyme extract. The test tubes containing the mixture were placed under light at $3000 \mathrm{~lx}$ for $10 \mathrm{~min}$, and absorbance at $560 \mathrm{~nm}$ was recorded. No purple color should appear in tubes without enzyme and NBT (CK 0). Tubes containing NBT but without enzyme should turn dark purple as the control (CK Max). One unit of SOD activity was defined as the amount of enzyme inhibiting 50\% photochemical reduction of NBT.

CAT activity was determined through the decomposition of hydrogen peroxide $\left(\mathrm{H}_{2} \mathrm{O}_{2}\right)$, which was measured by a decrease in absorbance at $240 \mathrm{~nm}\left(\varepsilon=39.4 \mathrm{M}^{-1} \cdot \mathrm{cm}^{-1}\right)$ for $1 \mathrm{~min}$ (Chance and Maehly, 1955). The reaction mixture consisted of $50 \mathrm{~mm}$ phosphate buffer ( $\mathrm{pH} 7.0$ ), $15 \mathrm{~mm} \mathrm{H}_{2} \mathrm{O}_{2}$, and $0.1 \mathrm{~mL}$ enzyme extract. 
Ascorbate peroxidase activity. APX activity was assayed by following the decline in absorbance at $290 \mathrm{~nm}$ as a result of ascorbate acid oxidation $\left(\varepsilon=2.8 \mathrm{~mm}^{-1} \cdot \mathrm{cm}^{-1}\right)$ for $1 \mathrm{~min}$. The reaction mixture contained $0.5 \mathrm{~mm}$ ascorbate acid, $0.1 \mathrm{~mm} \mathrm{H}_{2} \mathrm{O}_{2}, 0.1 \mathrm{~mm}$ EDTA, $50 \mathrm{~mm}$ Na-phosphate buffer ( $\mathrm{pH} 7.0$ ), and $0.1 \mathrm{~mL}$ enzyme extract. The reaction was initiated with addition of $\mathrm{H}_{2} \mathrm{O}_{2}$.

Peroxidase activity. The POD activity was measured as an increase in absorbance at $470 \mathrm{~nm}\left(\varepsilon=26.6 \mathrm{~mm}^{-1} \cdot \mathrm{cm}^{-1}\right)$ for 1 min after the oxidation of guaiacol (Rao et al., 1996). The reaction mixture contained $50 \mu \mathrm{L} 20 \mathrm{~mm}$ guaiacol, $2.83 \mathrm{~mL} 10 \mathrm{~mm}$ phosphate buffer (pH 7.0), $20 \mu \mathrm{L} 40 \mathrm{~mm} \mathrm{H}_{2} \mathrm{O}_{2}$, and $0.1 \mathrm{~mL}$ enzyme extract. The reaction was started with addition of the $\mathrm{H}_{2} \mathrm{O}_{2}$.

\section{Leaf malondialdehyde content}

The level of lipid peroxidation in the leaf tissue was measured in terms of malondialdehyde (MDA) content. The MDA content was determined by the 2-thiobarbituric acid (TBA) reaction according to Heath and Packer (1968). Fresh leaf tissue (100 mg) was ground into a powder with liquid $\mathrm{N}$ in a mortar with a pestle and homogenized in $2.5 \mathrm{~mL} 10 \%$ trichloroacid (TCA). The homogenate was heated at $95{ }^{\circ} \mathrm{C}$ for $30 \mathrm{~min}$ and the mixture was quickly cooled down in an ice bath. The homogenate was centrifuged at $10,000 g_{n}$ for $10 \mathrm{~min}$. One milliliter of supernatant was added to a tube containing $4 \mathrm{~mL} 20 \%$ TCA and $0.5 \%$ TBA. The mixture was heated at $95^{\circ} \mathrm{C}$ for $30 \mathrm{~min}$ and the mixture was quickly cooled down in an ice bath. The supernatant was read for absorbance at 532 and $600 \mathrm{~nm}$. The absorbance for nonspecific absorption at $600 \mathrm{~nm}$ was subtracted from the value at $532 \mathrm{~nm}$. The content of MDA was calculated using the adjusted absorbance and the extinction coefficient of $155 \mathrm{~mm}^{-1} \cdot \mathrm{cm}^{-1}$.

\section{Experimental design and statistical analysis}

A split plot with soil moisture as the main plot and biosolids treatments as subplots were used with four completely randomized replications. The data were subjected to an analysis of variance (ANOVA). In addition, one-way ANOVA was used for analysis of biosolids effect at each soil moisture level. Mean separations were performed using a protected Fisher's least significant difference at a 5\% probability level (SAS Institute Inc., 2004).

\section{Results}

Turf quality, leaf firing, and root growth. Turfgrass quality declined when the grass was subjected to moisture stress and recovered to above an acceptable level (i.e., greater than 6) after rewatering (Table 2). Turfgrass quality gradually declined beginning at $7 \mathrm{~d}$ after irrigation cessation. Drought stress reduced turfgrass quality by $30 \%$ at the end of the dry-down cycle (28 d).

Under well-watered conditions, Alexandria treatment improved turfgrass quality as measured at 14, 21, 28, and $35 \mathrm{~d}$ (Table 2).
Blue Plains also improved turfgrass quality at $35 \mathrm{~d}$. Under drought stress, the two biosolids increased turfgrass quality ratings from Day 14 through Day 35 except for Blue Plains treatment at $28 \mathrm{~d}$. At $21 \mathrm{~d}$, Alexandria and Blue Plains increased turfgrass quality by $15 \%$ under drought stress conditions.

The biosolids treatments reduced leaf firing as measured at 21 and $28 \mathrm{~d}$ of drought stress (Fig. 1). Alexandria and Blue Plains reduced leaf firing by $7 \%$ and $6 \%$, respectively, relative to the $\mathrm{N}$ control at $28 \mathrm{~d}$.

Drought stress induced an increase in root biomass relative to well-watered conditions (Table 3). Blue Plains treatment increased root biomass at 15 - to $30-\mathrm{cm}$ deep soil relative to the control under either well-watered or drought-stressed conditions. Alexandria increased root biomass in the $0-$ to $15-\mathrm{cm}$

fraction and total root biomass relative to the control.

Photochemical efficiency. Photochemical efficiency declined as the grass was subjected to moisture stress (Table 2). Drought stress reduced $\mathrm{PE}$ by $15 \%$ at $28 \mathrm{~d}$. Alexandria improved PE only at $28 \mathrm{~d}$ under well-watered conditions. Under moisture stress, Alexandria and Blue Plains improved PE by $16 \%$ at 28 d. Alexandria also increased PE when compared with the control at 14,21, and $35 \mathrm{~d}$.

Leaf superoxide dismutase activity. Drought stress induced an increase in SOD activity as observed at 21 and $28 \mathrm{~d}$ (Table 4). Both biosolids treatments increased SOD activity, when compared with the control, at 14 and 21d under well-watered conditions (Table 4). Under drought stress conditions, both biosolids increased SOD activity relative to

Table 2 . Turfgrass quality and photochemical efficiency as influenced by biosolids and soil moisture in tall fescue.

\begin{tabular}{|c|c|c|c|c|c|c|c|}
\hline \multirow[b]{2}{*}{ Moisture $^{\mathrm{z}}$} & \multirow[b]{2}{*}{ Treatment } & \multicolumn{6}{|c|}{ Days of soil moisture treatment $\mathrm{t}^{\mathrm{y}}$} \\
\hline & & 1 & 7 & 14 & 21 & 28 & 35 \\
\hline & & \multicolumn{6}{|c|}{ Turfgrass quality $(1-9,9=$ the best $)$} \\
\hline \multirow[t]{3}{*}{ Water+ } & Alexandria & $8.5 \mathrm{a}^{\mathrm{x}}$ & $8.5 \mathrm{a}$ & $8.5 \mathrm{a}$ & $8.5 \mathrm{a}$ & $8.5 \mathrm{a}$ & $8.5 \mathrm{a}$ \\
\hline & Blue Plains & $8.5 \mathrm{a}$ & $8.5 \mathrm{a}$ & $8.4 \mathrm{ab}$ & $8.4 \mathrm{ab}$ & $8.4 \mathrm{ab}$ & $8.5 \mathrm{a}$ \\
\hline & Control & $8.4 \mathrm{a}$ & $8.5 \mathrm{a}$ & $8.1 \mathrm{~b}$ & $8.1 \mathrm{~b}$ & $8.1 \mathrm{~b}$ & $8.0 \mathrm{~b}$ \\
\hline \multirow[t]{6}{*}{ Water- } & Alexandria & $8.5 \mathrm{a}$ & $8.4 \mathrm{a}$ & $7.4 \mathrm{a}$ & $6.8 \mathrm{a}$ & $6.3 \mathrm{a}$ & $8.1 \mathrm{a}$ \\
\hline & Blue Plains & $8.5 \mathrm{a}$ & $8.4 \mathrm{a}$ & $7.0 \mathrm{a}$ & $6.8 \mathrm{a}$ & $5.9 \mathrm{ab}$ & $8.1 \mathrm{a}$ \\
\hline & Control & $8.5 \mathrm{a}$ & $8.3 \mathrm{a}$ & $6.4 \mathrm{~b}$ & $5.9 \mathrm{~b}$ & $5.4 \mathrm{~b}$ & $7.3 \mathrm{~b}$ \\
\hline & Water+ & $8.5 \mathrm{x}$ & $8.5 \mathrm{x}$ & $8.3 \mathrm{x}$ & $8.3 x$ & $8.3 \times$ & $8.3 \mathrm{x}$ \\
\hline & Water- & $8.5 \mathrm{x}$ & $8.3 \mathrm{y}$ & $6.9 \mathrm{y}$ & $6.5 \mathrm{y}$ & $5.8 \mathrm{y}$ & $7.8 \mathrm{y}$ \\
\hline & & \multicolumn{6}{|c|}{ Photochemical efficiency $(F v / F m)$} \\
\hline \multirow[t]{3}{*}{ Water+ } & Alexandria & $0.761 \mathrm{a}$ & $0.701 \mathrm{a}$ & $0.749 \mathrm{a}$ & $0.749 \mathrm{a}$ & $0.773 \mathrm{a}$ & $0.698 \mathrm{a}$ \\
\hline & Blue Plains & $0.785 \mathrm{a}$ & $0.722 \mathrm{a}$ & $0.757 \mathrm{a}$ & $0.729 \mathrm{a}$ & $0.755 \mathrm{ab}$ & $0.700 \mathrm{a}$ \\
\hline & Control & $0.771 \mathrm{a}$ & $0.680 \mathrm{a}$ & $0.746 \mathrm{a}$ & $0.695 \mathrm{a}$ & $0.734 b$ & $0.628 \mathrm{a}$ \\
\hline \multirow[t]{5}{*}{ Water- } & Alexandria & $0.763 \mathrm{a}$ & $0.704 \mathrm{a}$ & $0.747 \mathrm{a}$ & $0.722 \mathrm{a}$ & $0.685 \mathrm{a}$ & $0.748 \mathrm{a}$ \\
\hline & Blue Plains & $0.777 \mathrm{a}$ & $0.736 \mathrm{a}$ & $0.720 \mathrm{ab}$ & $0.685 \mathrm{ab}$ & $0.685 \mathrm{a}$ & $0.727 \mathrm{ab}$ \\
\hline & Control & $0.759 \mathrm{a}$ & $0.714 \mathrm{a}$ & $0.694 \mathrm{~b}$ & $0.636 \mathrm{~b}$ & $0.592 \mathrm{~b}$ & $0.686 \mathrm{~b}$ \\
\hline & Water+ & $0.773 \times$ & $0.701 \mathrm{x}$ & $0.751 \times$ & $0.724 x$ & $0.753 \times$ & $0.675 \mathrm{y}$ \\
\hline & Water- & $0.766 \times$ & $0.718 x$ & $0.720 \mathrm{y}$ & $0.681 \mathrm{y}$ & $0.654 \mathrm{y}$ & $0.720 x$ \\
\hline
\end{tabular}

${ }^{\mathrm{z}}$ Water+ = well-watered; Water- $=$ drought stress

${ }^{\mathrm{y}}$ Irrigation was resumed at $28 \mathrm{~d}$ for drought stress (water-) treatment.

${ }^{x}$ Values followed by same letter within each column for each data set are not significantly different at $P \leq 0.05$.

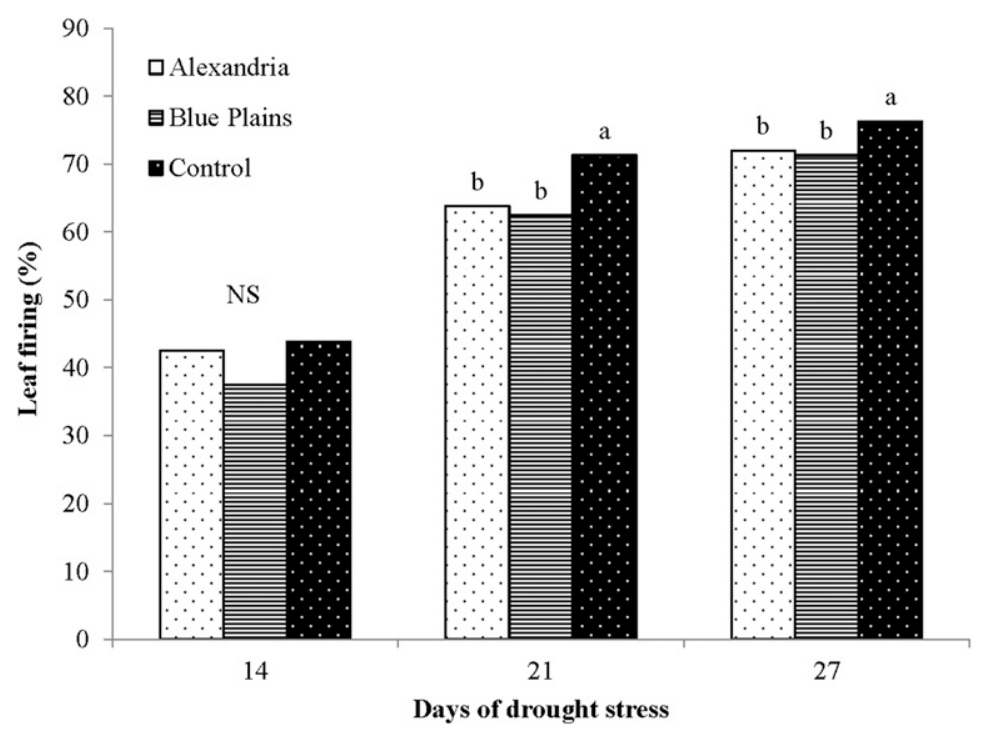

Fig. 1. Leaf firing (\%) responses to biosolids application in tall fescue grown under moisture stress. Treatments with the same letters within each sampling date are not significantly different at $P \leq 0.05$. 
the control at 14, 21, and $28 \mathrm{~d}$. Alexandria and Blue Plains increased SOD activity by $28 \%$ and $41 \%$, respectively, relative to the control at $28 \mathrm{~d}$ (Table 4).

Leaf catalase activity. Drought stress reduced CAT activity as measured at 14, 21, and $28 \mathrm{~d}$ (Table 4). Drought stress reduced CAT activity by $32 \%$ at $28 \mathrm{~d}$. The biosolids treatments did not consistently impact CAT activity under well-watered conditions. Alexandria increased CAT activity relative to the control at $28 \mathrm{~d}$. Both biosolids increased CAT activity at $35 \mathrm{~d}, 7 \mathrm{~d}$ after rewatering.

Leaf ascorbate peroxidase activity. Drought stress increased APX activity relative to the control as measured at 21 and $28 \mathrm{~d}$ (Table 5). A higher APX activity was also observed in drought-stressed tall fescue after rewatering (35 d). The two biosolids treatments increased APX activity under well-watered conditions at 21, 28, and $35 \mathrm{~d}$. Alexandria and Blue Plains increased APX activity by $44 \%$ and $33 \%$, respectively, relative to the control at $28 \mathrm{~d}$. Under drought stress, the biosolids treatments increased APX activity when compared with the control at 21 and $28 \mathrm{~d}$. Alexandria and Blue Plains increased APX activity by $49 \%$ and $23 \%$, respectively, when compared with the control at $28 \mathrm{~d}$. After watering ( $35 \mathrm{~d})$, a higher APX activity was observed in Blue Plains treatment relative to the control.

Leaf peroxidase activity. Drought stress caused an increase in POD activity as measured from Day 7 through Day 35 (Table 5). At end of drought stress (28d), tall fescue had 3.6-fold higher POD activity relative to the well-watered conditions. The two biosolids treatments increased POD activity under wellwatered conditions at 21,28 , and $35 \mathrm{~d}$, except for Blue Plains treatment at $28 \mathrm{~d}$. Under drought stress, the Alexandria treatment increased POD activity at $21 \mathrm{~d}$, whereas Blue Plains increased POD activity at $28 \mathrm{~d}$ and $35 \mathrm{~d}$.

Leaf malondialdehyde content. Leaf MDA content increased gradually in response to drought stress and declined after rewatering (Fig. 2). Leaf MDA content remained unchanged under well-watered conditions (data not shown). The biosolids treatments consistently reduced MDA content at Day 14 through Day 35. At the end of drought stress (28 d), the MDA contents in Alexandria and Blue Plainstreated tall fescue were $75 \%$ and $78 \%$, respectively, of the control.

\section{Discussion}

The results of this study indicate that biosolids application improved turfgrass quality and photochemical efficiency under drought stress. This is consistent with previously reported results (Garling and Boehm, 2001; Waddington et al., 1978; Zhang et al., 2005, 2009). Beneficial effects of the biosolids appear to result from factors other than mineral nutrition because all treatments in this study received an equivalent estimated amount of $\mathrm{N}$ and other macro- and micronutrients from chemical fertilizer or biosolids solids-fertilized crops have greater yields than crops fertilized with synthetic fertilizer where both were applied at rates estimated to provide adequate amounts of primary nutrients (Akrivos et al., 2000; Bugbee, 2002). Various BAS such as auxin and humic acids have been identified and isolated from biosolids previously (Lemmer and Nitschke, 1994; Sanchez-Monedero et al., 1999; Zhang et al., 2005) and in this study. Auxin and humic acids have been shown to increase root initiation and growth (O'Donnell, 1973; Zhang, et al., 2005, 2007). Auxin and humic acids in the biosolids could increase root growth and improve plant tolerance to drought stress (Zhang et al., 2005; 2009). plus fertilizer. It has been reported that bio-

Table 3. Root biomass as influenced by biosolids and soil moisture in tall fescue.

\begin{tabular}{lllrl}
\hline & & \multicolumn{3}{c}{ Root dry wt $(\mathrm{mg} / \text { tube })^{\mathrm{y}}$} \\
\cline { 3 - 5 } Moisture $^{\mathrm{z}}$ & Treatment & $0-15 \mathrm{~cm}$ & $15-30 \mathrm{~cm}$ & Total \\
\hline Water+ & Alexandria & $199 \mathrm{a}^{\mathrm{x}}$ & $77 \mathrm{ab}$ & $276 \mathrm{a}$ \\
& Blue Plains & $201 \mathrm{a}$ & $81 \mathrm{a}$ & $282 \mathrm{a}$ \\
\multirow{4}{*}{ Water- -} & Control & $195 \mathrm{a}$ & $66 \mathrm{~b}$ & $262 \mathrm{a}$ \\
& Alexandria & $281 \mathrm{a}$ & $98 \mathrm{~b}$ & $379 \mathrm{a}$ \\
& Blue Plains & $233 \mathrm{ab}$ & $114 \mathrm{a}$ & $347 \mathrm{ab}$ \\
& Control & $201 \mathrm{~b}$ & $91 \mathrm{~b}$ & $292 \mathrm{~b}$ \\
& Water+ & $198 \mathrm{y}$ & $75 \mathrm{y}$ & $273 \mathrm{y}$ \\
& Water- & $238 \mathrm{x}$ & $101 \mathrm{x}$ & $399 \mathrm{x}$ \\
\hline
\end{tabular}

${ }^{2}$ Water $+=$ well-watered; Water- $=$ drought stress. ${ }^{\mathrm{y}}$ Root mass was measured at the end of the experiment (5 Jan. 2011).

${ }^{x}$ Values followed by same letters within same column for each data set are not significantly different at $P \leq 0.05$.

Table 4. Leaf superoxide dismutase (SOD) and catalase (CAT) activity as influenced by biosolids and soil moisture in tall fescue.

\begin{tabular}{|c|c|c|c|c|c|c|c|}
\hline \multirow[b]{2}{*}{ Moisture $^{\mathrm{z}}$} & \multirow[b]{2}{*}{ Treatment } & \multicolumn{6}{|c|}{ Days of soil moisture treatment ${ }^{y}$} \\
\hline & & 1 & 7 & 14 & 21 & 28 & 35 \\
\hline & & \multicolumn{6}{|c|}{ SOD activity (U.mg ${ }^{-1}$ protein) } \\
\hline \multirow[t]{3}{*}{ Water+ } & Alexandria & $348.3 \mathrm{a}^{\mathrm{x}}$ & $447.3 \mathrm{a}$ & $441.5 \mathrm{a}$ & $436.8 \mathrm{a}$ & $417.5 \mathrm{a}$ & $410.8 \mathrm{a}$ \\
\hline & Blue Plains & $345.0 \mathrm{a}$ & $444.3 \mathrm{a}$ & $427.5 \mathrm{a}$ & $437.5 \mathrm{a}$ & $380.0 \mathrm{a}$ & $407.0 \mathrm{a}$ \\
\hline & Control & $352.8 \mathrm{a}$ & $433.3 \mathrm{a}$ & $399.8 \mathrm{~b}$ & $407.5 \mathrm{~b}$ & $372.3 \mathrm{a}$ & $383.0 \mathrm{a}$ \\
\hline \multirow[t]{6}{*}{ Water- } & Alexandria & $345.8 \mathrm{a}$ & $436.0 \mathrm{a}$ & $443.3 \mathrm{a}$ & $760.3 \mathrm{a}$ & $757.8 \mathrm{~b}$ & $535.8 \mathrm{a}$ \\
\hline & Blue Plains & $361.5 \mathrm{a}$ & $440.0 \mathrm{a}$ & $455.5 \mathrm{a}$ & $814.3 \mathrm{a}$ & $833.5 \mathrm{a}$ & $551.3 \mathrm{a}$ \\
\hline & Control & $352.5 \mathrm{a}$ & $403.5 \mathrm{a}$ & $375.0 \mathrm{~b}$ & $608.8 \mathrm{~b}$ & $590.5 \mathrm{c}$ & $444.5 \mathrm{a}$ \\
\hline & Water+ & $348.7 x$ & $441.6 \mathrm{x}$ & $422.9 \times$ & $427.3 \mathrm{y}$ & 389.9 y & $400.3 \mathrm{y}$ \\
\hline & Water- & $353.3 \mathrm{x}$ & $426.5 \mathrm{x}$ & $424.6 x$ & $727.8 x$ & $727.3 x$ & $510.5 \mathrm{x}$ \\
\hline & & \multicolumn{6}{|c|}{ CAT activity $\left(\mu \mathrm{mol} \cdot \mathrm{min}^{-1} \cdot \mathrm{mg}^{-1}\right.$ protein $)$} \\
\hline \multirow[t]{3}{*}{ Water+ } & Alexandria & $417.9 \mathrm{a}$ & $513.8 \mathrm{a}$ & $454.8 \mathrm{a}$ & $426.8 \mathrm{a}$ & $421.5 \mathrm{a}$ & $454.0 \mathrm{~b}$ \\
\hline & Blue Plains & $426.2 \mathrm{a}$ & $478.8 \mathrm{a}$ & $466.3 \mathrm{a}$ & $422.8 \mathrm{a}$ & $433.5 \mathrm{a}$ & $547.0 \mathrm{a}$ \\
\hline & Control & $412.7 \mathrm{a}$ & $471.0 \mathrm{~b}$ & $444.3 \mathrm{a}$ & $410.8 \mathrm{a}$ & $415.5 \mathrm{a}$ & $409.5 \mathrm{~b}$ \\
\hline \multirow[t]{5}{*}{ Water- } & Alexandria & $419.0 \mathrm{a}$ & $492.8 \mathrm{a}$ & $367.8 \mathrm{a}$ & $323.0 \mathrm{a}$ & $290.3 \mathrm{a}$ & $283.8 \mathrm{a}$ \\
\hline & Blue Plains & $408.5 \mathrm{a}$ & $503.5 \mathrm{a}$ & $363.5 \mathrm{a}$ & $299.5 \mathrm{a}$ & $273.3 \mathrm{ab}$ & $292.5 \mathrm{a}$ \\
\hline & Control & $401.0 \mathrm{a}$ & $505.5 \mathrm{a}$ & $381.0 \mathrm{a}$ & $301.0 \mathrm{a}$ & $244.3 \mathrm{~b}$ & $229.8 \mathrm{~b}$ \\
\hline & Water+ & $418.9 \times$ & $487.8 \times$ & $455.1 \mathrm{x}$ & $420.1 \mathrm{x}$ & $423.5 \mathrm{x}$ & $470.2 \times$ \\
\hline & Water- & $409.5 \times$ & $500.8 \times$ & $370.8 \mathrm{y}$ & $307.8 \mathrm{y}$ & $289.3 \mathrm{y}$ & $268.7 \mathrm{y}$ \\
\hline
\end{tabular}

${ }^{2}$ Water $+=$ well-watered; Water $-=$ drought stress.

y Irrigation was resumed at $28 \mathrm{~d}$ for drought stress (water-) treatment.

${ }^{x}$ Values followed by same letter within each column for each data set are not significantly different at $P \leq 0.05$.

Table 5. Leaf ascorbate peroxidase (APX) and peroxidase (POD) activity as influenced by biosolids and soil moisture in tall fescue.

\begin{tabular}{|c|c|c|c|c|c|c|c|}
\hline \multirow{2}{*}{ Moisture ${ }^{\mathrm{z}}$} & \multirow[b]{2}{*}{ Treatment } & \multicolumn{6}{|c|}{ Days of soil moisture treatment ${ }^{y}$} \\
\hline & & 1 & 7 & 14 & 21 & 28 & 35 \\
\hline & & \multicolumn{6}{|c|}{ APX activity $\left(\mathrm{nmol} \cdot \mathrm{min}^{-1} \cdot \mathrm{mg}^{-1}\right.$ protein) } \\
\hline \multirow[t]{3}{*}{ Water+ } & Alexandria & $0.248 \mathrm{a}^{\mathrm{x}}$ & $0.240 \mathrm{a}$ & $0.280 \mathrm{a}$ & $0.273 \mathrm{a}$ & $0.238 \mathrm{a}$ & $0.195 \mathrm{a}$ \\
\hline & Blue Plains & $0.240 \mathrm{a}$ & $0.250 \mathrm{a}$ & $0.268 \mathrm{a}$ & $0.258 \mathrm{a}$ & $0.220 \mathrm{a}$ & $0.200 \mathrm{a}$ \\
\hline & Control & $0.230 \mathrm{a}$ & $0.245 \mathrm{a}$ & $0.265 \mathrm{a}$ & $0.193 \mathrm{~b}$ & $0.165 \mathrm{~b}$ & $0.158 \mathrm{~b}$ \\
\hline \multirow[t]{6}{*}{ Water- } & Alexandria & $0.248 \mathrm{a}$ & $0.235 \mathrm{a}$ & $0.305 \mathrm{a}$ & $0.500 \mathrm{~b}$ & $0.690 \mathrm{a}$ & $0.470 \mathrm{~b}$ \\
\hline & Blue Plains & $0.253 \mathrm{a}$ & $0.235 \mathrm{a}$ & $0.280 \mathrm{a}$ & $0.555 \mathrm{a}$ & $0.570 \mathrm{~b}$ & $0.563 \mathrm{a}$ \\
\hline & Control & $0.233 \mathrm{a}$ & $0.255 \mathrm{a}$ & $0.290 \mathrm{a}$ & $0.443 \mathrm{c}$ & $0.463 \mathrm{c}$ & $0.425 \mathrm{~b}$ \\
\hline & Water+ & $0.239 x$ & $0.245 \mathrm{x}$ & $0.271 \mathrm{x}$ & $0.241 \mathrm{y}$ & $0.280 \mathrm{y}$ & $0.184 \mathrm{y}$ \\
\hline & Water- & $0.244 \mathrm{x}$ & $0.242 \times$ & $0.292 \times$ & $0.495 \times$ & $0.574 \mathrm{x}$ & $0.486 \mathrm{x}$ \\
\hline & & \multicolumn{6}{|c|}{ POD activity $\left(\mu \mathrm{mol} \cdot \mathrm{min}^{-1} \cdot \mathrm{mg}^{-1}\right.$ protein $)$} \\
\hline \multirow[t]{3}{*}{ Water+ } & Alexandria & $0.113 \mathrm{a}$ & $0.105 \mathrm{a}$ & $0.123 \mathrm{a}$ & $0.123 \mathrm{a}$ & $0.115 \mathrm{a}$ & $0.120 \mathrm{a}$ \\
\hline & Blue Plains & $0.123 \mathrm{a}$ & $0.113 \mathrm{a}$ & $0.120 \mathrm{a}$ & $0.128 \mathrm{a}$ & $0.103 \mathrm{ab}$ & $0.125 \mathrm{a}$ \\
\hline & Control & $0.100 \mathrm{a}$ & $0.110 \mathrm{a}$ & $0.110 \mathrm{a}$ & $0.100 \mathrm{~b}$ & $0.078 \mathrm{~b}$ & $0.095 b$ \\
\hline \multirow[t]{5}{*}{ Water- } & Alexandria & $0.120 \mathrm{a}$ & $0.193 \mathrm{a}$ & $0.173 \mathrm{a}$ & $0.533 \mathrm{a}$ & $0.428 \mathrm{~b}$ & $0.298 \mathrm{~b}$ \\
\hline & Blue Plains & $0.113 \mathrm{a}$ & $0.192 \mathrm{a}$ & $0.170 \mathrm{a}$ & $0.348 \mathrm{~b}$ & $0.538 \mathrm{a}$ & $0.405 \mathrm{a}$ \\
\hline & Control & $0.100 \mathrm{a}$ & $0.145 \mathrm{a}$ & $0.155 \mathrm{a}$ & $0.263 \mathrm{~b}$ & $0.378 \mathrm{~b}$ & $0.273 \mathrm{~b}$ \\
\hline & Water+ & $0.112 \times$ & $0.109 \mathrm{y}$ & $0.118 \mathrm{y}$ & $0.117 \mathrm{y}$ & $0.098 \mathrm{y}$ & $0.113 \mathrm{y}$ \\
\hline & Water- & $0.111 \mathrm{x}$ & $0.177 \mathrm{x}$ & $0.166 \mathrm{x}$ & $0.381 \mathrm{x}$ & $0.448 \mathrm{x}$ & $0.325 \mathrm{x}$ \\
\hline
\end{tabular}

${ }^{2}$ Water $+=$ well-watered; Water- $=$ drought stress.

${ }^{\mathrm{y}}$ Irrigation was resumed at $28 \mathrm{~d}$ for drought stress (water-) treatment.

${ }^{x}$ Values followed by same letter within each column for each data set are not significantly different at $P \leq 0.05$. 


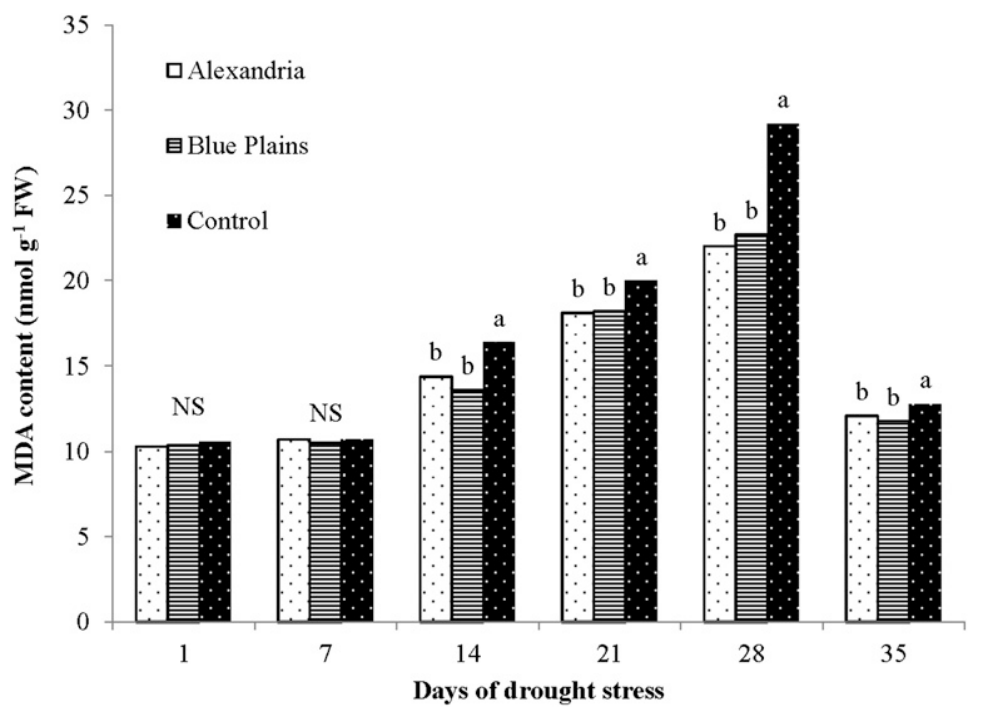

Fig. 2. Leaf malondialdehyde (MDA) content responses to biosolids application in tall fescue grown under drought stress. Tall fescue was seeded on 8 Oct. 2010; biosolids were applied $1 \mathrm{~d}$ before planting. Irrigation was withheld from $1 \mathrm{~d}$ to $28 \mathrm{~d}$ and then resumed from $28 \mathrm{~d}$ to $35 \mathrm{~d}$. Treatments with same letters are not significantly different at $P \leq 0.05$.

Grasses with greater root systems resulting from biosolids application may have better leaf water status, reducing leaf wilting during drought stress. In this study, Blue Plains, which contained a higher level of auxin $\left(17.2 \mu \mathrm{g} \cdot \mathrm{g}^{-1}\right)$ relative to Alexandria, significantly increased biomass of roots distributed between 15 and $30 \mathrm{~cm}$ deep in the soil under well-watered and drought stress conditions. It is possible that biosolids promoted root growth and turfgrass quality by providing auxin and/or stimulating microbial production of auxin and other growth hormones. Because auxin is closely associated with root initiation and growth, application of auxin-containing biosolids may have greater beneficial effects on relatively young turfgrass with an actively growing root system as in this study than mature turfgrass with a lowly growing root system.

The results of this study also indicate that the biosolids enhanced leaf antioxidant enzyme activity, especially SOD and APX, under drought stress. These responses have been reported previously (Lakhdar et al., 2010; Zhang et al., 2005, 2009). Lakhdar et al. (2010) noted that municipal solid waste (MSW) compost and sewage sludge significantly increased activities of antioxidant enzymes including SOD, CAT, APX, and glutathione reductase in wheat. Drought stress causes excess accumulation of toxic ROS in cells. The ROS may cause damage to cell components, particularly those associated with the photosynthetic apparatus (Smirnoff, 1995). Plants possess various antioxidant metabolites and enzymes that can scavenge toxic ROS and protect cells under stress. The results of this study indicate that the grass amended with biosolids had greater antioxidant enzyme (SOD, APX, CAT, and POD) activities under drought stress. This suggests that biosolids treatment may promote antioxidant defenses against drought stress possibly through hormonal signaling. Zhang et al.
(2009) noted that tall fescue amended with biosolids contained higher levels of growth hormones (auxin and cytokinin) and also SOD activity under drought stress. The mechanics of how greater auxin and cytokinins positively impact the leaf antioxidant enzyme system are not known. It is possible that the growth hormones serve as signals to initiate metabolic defenses including upregulation of antioxidant enzyme activities under drought stress.

In summary, the two biosolids (Alexandria and Blue Plains) improved turfgrass quality, PE, and antioxidant enzyme activities under drought stress. Beneficial effects of these biosolids did not appear to be nutritional in origin because all treatments received identical nutrient inputs. It is our view that the biosolids may enhance plant antioxidant defense systems through providing certain BAS such as auxin to the soil or by providing organic substrates for soil microbial production of growth hormones. Application of biosolids appears to be a practical and cost-effective organic approach for improving turfgrass performance when faced with periodic abiotic stresses such as drought.

\section{Literature Cited}

Akrivos, J., D. Mamais, K. Katsara, and A. Andreadakis. 2000. Agricultural utilization of lime treated sewage sludge. Water Sci. Technol. 42:203-210

American Water Works Association. 1998. Standard methods for the examination of water and wastewater $\left(20^{\text {th }}\right.$ edition). Co-published by AWWA, American Public Health Association (APHA), and Water Environment Federation (WEF), Washington, DC.

Arshad, M. and W.T. Frankenberger, Jr. 1993. Microbial production of plant growth regulators, p. 307-348. In: Metting, F.B., Jr. (ed.). Soil microbial ecology-Application in agricultural and environmental management. Marcel Dekker, New York, NY.
Barea, J.M., E. Navarro, and E. Montoya. 1976. Production of plant growth regulators by rhizosphere phosphate-solubilizing bacteria. J. Appl. Bacteriol. 40:129-134.

Boquet, D.J., G.A. Breitenbeck, and C.B. Coreil, Jr. 1999. Beneficial use of municipal and industrial wastes in cotton production. Louisiana Agr. 42:10-11.

Bugbee, G.J. 2002. Growth of ornamental plants in container media amended with biosolids compost. Compost Sci. Util. 10:92-98.

Chance, B. and A.C. Maehly. 1955. Assay of catalases and peroxidases. Methods Enzymol. 2:764-775.

Edlund, A., S. Eklof, B. Sundberg, T. Moritz, and G. Sandberg. 1995. A microscale technique for gas chromatography-mass spectrometry measurements of picogram amounts of indole3 -acetic acid in plant tissues. Plant Physiol. 108:1043-1047.

Garling, D.C. and M.J. Boehm. 2001. Temporal effects of compost and fertilizer applications on nitrogen fertility of golf course turfgrass. Agron. J. 93:548-555.

Giannopolitis, C.N. and S.K. Ries. 1977. Superoxide dismutase. I. Occurrence in higher plants. Plant Physiol. 59:309-314.

Gilmour, J.T., C.G. Cogger, L.W. Jacobs, G.K. Evanylo, and D.M. Sullivan. 2003. Decomposition and plant available nitrogen in biosolids: Laboratory studies, field studies, and computer simulation. J. Environ. Qual. 32:14981507.

Heath, R.L. and L. Packer. 1968. Photoperoxidation in isolated chloroplasts. I. Kinetics and stoichiometry of fatty acid peroxidation. Arch. Biochem. Biophys. 125:180-198.

Hoagland, D.R. and D.I. Arnon. 1950. The waterculture method for growing plants without soil. Calif. Agr. Exp. Stn. Circular. 347:32.

Klock-Moore, K.A. 2000. Comparison of Salvia growth in seaweed compost and biosolids compost. Compost Sci. Util. 8:24-28.

Lakhdar, A., M.A. Iannell, A. Debez, A. Massacci, N. Jedidi, and C. Abdelly. 2010. Effects of municipal solid waste compost and sewage sludge on wheat (Triticum durum): Growth, heavy metal accumulation, and antioxidant activity. J. Sci. Food Agr. 90:965-971.

Lebuhn, M., T. Heulin, and A. Hartman. 2007. Production of auxin and other indolic and phenolic compounds by paenibacillus polymaxa strains isolated from different proximity to plants roots. FEMS Microbiol. Ecol. 22:325334.

Lemmer, H. and L. Nitschke. 1994. Vitamin content of four sludge fractions in the activated sludge wastewater treatment processes. Water Resour. 28:737-739.

O'Donnell, R.W. 1973. The auxin-like effects of humic preparations from leonardite. Soil Sci. 116:106-112.

Perl-Treves, R. and A. Perl. 2002. Oxidative stress: An introduction, p. 1-32. In: Inze, D. and M. Van Montagu (eds.). Oxidative stress in plants. Taylor \& Francis, London, UK

Rao, M.V., G. Paliyath, and D.P. Ormrod. 1996. Ultraviolet-B- and ozone-induced biochemical changes in antioxidant enzymes of Arabidopsis thaliana. Plant Physiol. 110:125-136.

Sanchez-Monedero, M.A., A. Roig, J. Cegarra, and M.P. Bernal. 1999. Relationships between water-soluble carbohydrate and phenol fractions and the humification indices of different organic wastes during composting. Bioresour. Technol. 70:193-201.

SAS Institute Inc. 2004. SAS 9.1.3. SAS Institute Inc., Cary, NC. 
Smirnoff, N. 1995. Antioxidant systems and plant response to the environment. p. 217-244. In: Smirnoff, N. (ed.). Environment and plant metabolism: Flexibility and acclimation. BIOS Scientific Publishers, Oxford, UK.

Strivastava, L.M. 2002. Plant growth and development: Hormones and environment. Academic Press, San Diego, CA.

Subler, S., J. Dominguez, and C.A. Edwards. 1998. Assessing biological activity of agricultural biostimulants: Bioassays for plant growth regulators in three soil additives. Commun. Soil Sci. Plant Anal. 29:859-866.

Tester, C.F. 1989. Tall fescue growth in greenhouse, growth chamber and field plots amended with sewage sludge compost and fertilizer. Soil Sci. 148:452-458.

U.S. EPA. 1979. Methods for chemical analysis of water and wastes (EPA/600/4-79/020). Natl. Tech. Info. Svc., Springfield, VA.
U.S. EPA. 2007. Biosolids. 10 Oct. 2010. <http:// www.epa.gov/owm/mtb/biosolids/>.

Waddington, D.V., R.N. Carrow, and R.C. Shearman (eds.). 1992. Turfgrass. Agron. Monogr. 32. ASA, CSSA, and SSSA, Madison, WI.

Waddington, D.V., T.R. Turner, J.M. Duich, and E.L. Moberg. 1978. Effect of fertilization on Penncross creeping bentgrass. Agron. J. 70:713718.

Zhang, J. and M.B. Kirkham. 1996. Enzymatic responses of the ascorbate-glutathione cycle to drought in sorghum and sunflower plants. Plant Sci. 113:139-147.

Zhang, X. and E.H. Ervin. 2004. Cytokinincontaining seaweed and humic acid extracts associated with creeping bentgrass leaf cytokinins and drought resistance. Crop Sci. 44 1737-1745.

Zhang, X., E.H. Ervin, G.K. Evanylo, and K. Haering. 2007. Drought assessment of auxin-boosted biosolids, p. 150-165. In: Proc. of Water Environment Federation (WEF)/AWWA Joint Residuals and Biosolids Management Conference, Denver, CO, 15-18 Apr.

Zhang, X., E.H. Ervin, G.K. Evanylo, and K. Haering. 2009. Impact of biosolids on hormone metabolism in drought-stressed tall fescue. Crop Sci. 49:1893-1901.

Zhang, X., E.H. Ervin, G. Evanylo, C. Sherony, and C. Peot. 2005. Biosolids impact on tall fescue drought resistance. J. Residuals Sci. Technol. 2:173-180.

Zhang, X. and R.E. Schmidt. 1999. Antioxidant responses to hormone-containing product in kentucky bluegrass subjected to drought. Crop Sci. 39:545-551.

Zhang, X. and R.E. Schmidt. 2000. Hormonecontaining products' impact on antioxidant status of tall fescue and creeping bentgrass subjected to drought. Crop Sci. 40:1344-1349. 